\title{
BULGARIAN PERSONAL NAMES THAT REFER TO PRECIOUS STONES, METALS, AND JEWELRY
}

\author{
Gergana Petkova ${ }^{1}$ \\ Medical University - Plovdiv, Bulgaria \\ VANYA IVANOVA ${ }^{2}$ \\ University of Plovdiv, Bulgaria
}

\begin{abstract}
In the old folk tradition personal names were divided into two major groups in accordance with their semantics - names that somehow protected the baby from death, diseases, something evil, etc., and names that wished him/her to be handsome/beautiful, kind, strong, healthy, brave, to live long, and so on.

The researched anthroponyms are classified according to 1) the type of the basic word used during their derivation, as a part of speech; 2) the meaning of the word used as a basis in the derivation process; 3 ) the function of the name (to protect the newborn or to wish them good fortune).
\end{abstract}

Keywords: Bulgarian forenames, precious stones, jewelry.

Nowadays there are no strict rules determined by law regarding the choice of forenames for newborn babies in Bulgaria. It depends on the common sense and the good taste of the future parents. The only restrictions with which the parents have to comply are as follows: to decide on a name together and to eliminate all offending variations; if they are unable to find an appropriate anthroponym, the representative of the administration has to help them with that (Kovachev 1995: 8).

Some decades ago the rules were different, sometimes even too strict. Back then there were lists containing a limited number of recommended names described as traditional Bulgarian ones, and no exceptions were welcomed. This greatly encouraged the saving of old anthroponyms and their being in use even nowadays, although not very often.

1 Gergana Petkova's participation in the prestigious scientific event the Fourth International Conference on Onomastics "Name and Naming" (ICONN), Baia Mare, Romania, September 5-7, 2017, is possible with the kind help of the affiliation, Medical University - Plovdiv (Bulgaria), and in particular Project № BG05M2OP001-2.009-0025 "Doctoral Training at Medical University Plovdiv for Competency, Creativity, Originality, Accomplishment and Academic Excellence in Science and Technologies - 2 (DOCTORANT - 2)", funded by the Operational Programme "Science and Education for Smart Growth", part-financed by the European Union through Structural and Investment Funds.

2 Vanya Ivanova's participation is partially supported by the project of the Scientific Fund of the University of Plovdiv Paisii Hilendarski FP17-FMI-008, Bulgaria. 
Another extralinguistic factor that also helps their "conservation" consists of a very popular practice, i.e. naming a newborn after one of his/her (usually patrilineal) grandparents. In this action lies the idea that by taking one of the ancestors' names, the child receives his or her spiritual protection as well. Due to the influence of Christianity, so-called Calendar or saints' names have been used with the same function (Kovachev 1987b: 124).

While in present times more attention is paid to the form of the given anthroponym, along with its popularity and internationality, in the past people believed that its meaning was of the greatest importance. They put the focus on its majestic power, regardless of whether it was Slavonic or foreign by origin (Kovachev 1995: 17).

That is why in the old folk tradition personal names were divided into two major groups according to their semantics - names that somehow protected the baby from death, diseases, something evil, etc., and names that wished him/her to be handsome/ beautiful, kind, strong, healthy, brave, to live long, and so on. (Kovachev 1995: 17).

The research object of the present paper consists of 33 male and 38 female Bulgarian forenames whose meaning is related to precious stones, metals, and jewelry. The main aim is to present their full list, including all the anthroponyms derived from them, as well as their initial meaning ${ }^{3}$.

The main sources of information for excerpting the researched names are Ilchev (1959), Kovachev 1987, 1995), and Zaimov (1994).

The examples found are categorized according to 1) the type of the basic word used during their derivation, as a part of speech (i.e. if the researched forename is derived directly from an appellative or via another anthroponym); 2) the meaning of the word used as a basis in the derivation process (i.e. a thematic classification); 3 ) the function of the name (i.e. to protect the newborn or to wish him/her good fortune).

All the personal names included in this research pertain to the modern Bulgarian anthroponymicon, but their initial meaning is not completely clear for everybody nowadays. That is why it is of great importance to reveal the basic appellative.

None of the forenames included is a saint's name.

\section{Classification according to the basic word types of the researched anthroponyms as parts of speech}

1. Bulgarian forenames derived from proper nouns:

A. Male anthroponyms: Гривно $<$ Гривна $/ Г р и в н я{ }^{4}$; Ажемо < Ажема; Есмералд $<$ Есмералда; Круне/Круньо < Круна; Малам < Малама; Мено < Мена; Плумо < Пиума; Смарагд < Смарагаа;

В. Female anthroponyms: Аргира < Аргир; Бисера $<$ Бисер; Бриялнта $<$

\footnotetext{
3 The information about the names derived from the researched anthroponyms and the sources of excerption used are given in the indexes at the end of the article.

4 Sometimes more than an official variant of a given forename is presented in the text based on the area of its use. In the Western part of the country the first form is used, while in the Eastern - the second (Ilchev 1959: 19).
} 
Брилянт; Гердана < Гердан; Ажема < Јетта; Аиаманда < Аиаманди; Елмаза < Елмаз; Замфира < Замфир; Рубина < Рубин;

2. Bulgarian forenames derived from appellatives:

A. From common nouns:

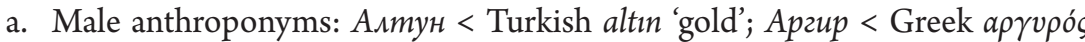
'silver'; Аржентин < Romanian argint 'silver'; Бисер < Bulgarian бuсер 'pearl'; Брилянт < Bulgarian брилянт 'brilliant'; Гердан < Bulgarian гердан 'necklace'; Аиаманди <

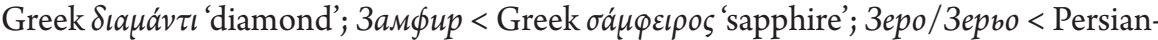
Turkish zer 'gold'; Mapzapum < Bulgarian мapzapum 'pearl'; Meдaı < Russian медаль 'medal'; Обецан < Bulgarian (dialect) обецан 'a male with an earring in his ear'; Рубин <

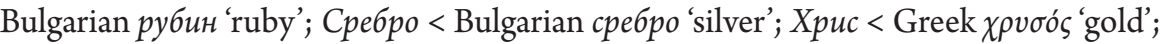
Хриса $\phi<$ Greek $\chi \rho v \sigma a ́ \varphi ı$ 'gold';

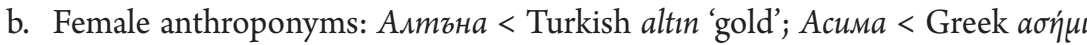
'silver'; Гривна/Гривня < Bulgarian гривна/гривня 'bracelet'; Ажофера < Bulgarian

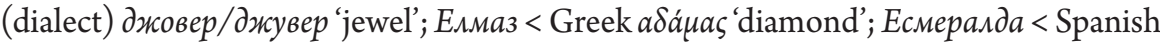
esmeralda 'emerald'; Золотинка < Russian золото 'gold'; Корона < Russian корона

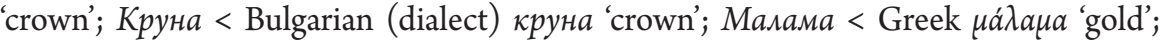
Мена < Bulgarian (dialect) мена 'engagement ring'; Обица < Bulgarian обица 'earring';

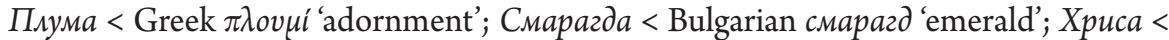

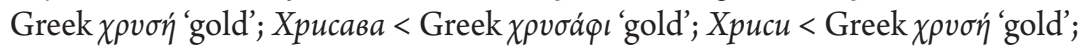

B. From an adjective:

a. Male anthroponyms: Aımyн < Turkish altın 'golden'; Aypes < Latin aureus, 3 'golden; gold-plated, gilded'; 3ıат < Bulgarian (dialect) злат 'golden'; Маламатен < Bulgarian (dialect) маламатен 'golden; gilded'; Маламен < Bulgarian (dialect) маламатен 'golden; gilded'; Сребрен < Bulgarian (dialect) сребрен '(made of, resembling) silver, argentine'; Сребър < Bulgarian (dialect) сребър '(made of, resembling) silver, argentine'; Xpuc < Greek $\chi \rho v \sigma o ́ s$ 'golden';

b. Female anthroponyms: A^mъна < Turkish altın 'golden'; Apгupude < Greek

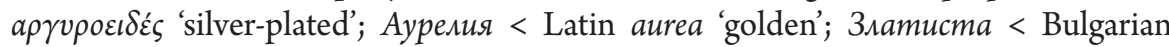
златиста 'golden'; Сребряна < Bulgarian (dialect) среберена '(made of, resembling) silver, argentine'; Сребърна < Bulgarian сребърна ' (made of, resembling) silver, argen-

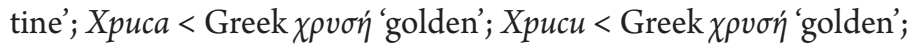

C. Bulgarian forenames with more than a supposed etymology:

a. Male anthroponyms: Eıма3 < 1) Bulgarian елма3, 2) Eıма3;

b. Female anthroponyms: Аржентина < 1) Аржентин, 2) Latin Argentum, i, n, 'silver'; 3ıama < 1) 3ıam, 2) Bulgarian зıаmo 'gold'; Mapzapuma < 1) Maprapum,

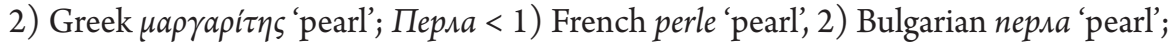
Сребра < 1) Сребро, 2) Сребър; Хрисафи < 1) Greek хрvбáфi 'gold', 2) Хрисаф.

In general the choice of a personal name is a limited act. It is not obvious at first glance that many extralinguistic factors play an important role, such as old folk traditions, family rules, laws, and the official religion in a country (Theory 1986: 19). As a 
result of the aforementioned factors, together with the wish of certain family members to save the patronyms and matronyms traditionally used in their kin, one can quite often observe the tendency for a female anthroponym to be derived from a male one and vice versa (Felecan 2009: 403).

In this research only 9 male and 9 female forenames are derived from another anthroponym. While all the masculine examples in that group are coined from feminine ones, which are already a part of the Bulgarian anthroponymic system, it is not the same with the female forenames - one of them is derived from an English feminine personal name.

Appellatives, particularly common nouns, are more productive than proper nouns in our classification. Four examples, А^тун, А^тәна, Xpис, and Xpuca, are part of both noun and adjective groups.

One of the male forenames has more than a supposed etymology. The number of female anthroponyms in the same group is 6 due to the hypothesis that it is derived either from an existing masculine name or directly from the basic appellative.

\section{Thematic classification}

1. Bulgarian forenames with the initial meaning referring to a precious metal:

A. Male anthroponyms: Алтун, Аргир, Аржентин, Аурел, Зеро/Зерьо, 3лат, Малам, Маламатен, Маламен, Сребрен, Сребро, Сребгр, Хрис, Хрисаф;

B. Female anthroponyms: Алтьна, Аргира, Алгириде, Аржентина, Асима, Аурелия, Злата, Златиста, Золотинка, Малама, Сребра, Сребряна, Сребърна, Хриса, Хрисава, Хрисафи, Хриси;

2. Bulgarian forenames with the initial meaning referring to a precious stone or pearl:

A. Male anthroponyms: Бисер, Брияянт, Аиаманди, Елмаз, Есмералд, Замфир, Маргарит, Рубин, Смарагд;

B. Female anthroponyms: Бисера, Брияянта, Аиаманда, Елмаз, Елмаза, Есмералда, Замфира, Маргарита, Перла, Рубина, Смарагда;

3. Bulgarian forenames with the initial meaning referring to a jewel:

A. Male anthroponyms: Гердан, Гривно, Ажемо, Круне/Круньо, Мено, Обецан, Пиумо;

B. Female anthroponyms: Гердана, Гривна/Гривня, Ажема, Ажофера, Корона, Круна, Мена, Обииа, Пиума;

4. Bulgarian forenames whose meaning refers to a symbol of a heroic deed:

A. Male anthroponyms: Medas.

15 male forenames (out of 33) and 17 female ones (out of 38) are derived from an appellative with the meaning referring to a precious metal. They are followed by the groups of names whose meaning refers to a precious stone or a pearl and jewelry. There is only a masculine anthroponym coined from a noun for a symbol of a heroic deed, but it is probably an occasionym in the system. 
There are examples with the same semantics but a different origin. They form the following synonymous clusters: 1a) А^тун, Аурел, Зеро/Зерьо, Злат, Малам, Маламатен, Маламен, Хрис, Хрисаф; 1b) Алтьна, Аурелия, Злата, Златиста, Золотинка,Малама, Хриса, Хрисава, Хрисафи, Хриси (<'gold'); 2a) Аргир, Аржентин, Сребрен, Сребро, Сребър; 2b) Аргира, Алгириде, Аржентина, Асима, Сребра, Сребряна, Сребърна (< 'silver'); 3a) Бисер, Маргарит; 3b) Бисера, Маргарита, Перла (<'pearl'); 4а) Брилянт, Аиаманди, Елмаз; 4b) Брилянта, Аиаманда, Елмаз, Елмаза (<'diamond'); 5а) Есмералд, Смарагд; 5b) Есмералда, Смарагда (< 'emerald'); 6) Ажема, Ажофера (<'jewel'); 7) Корона, Круна (< 'crown').

\section{Classification of Bulgarian forenames according to their function to protect the newborn or to wish him/ her good fortune, used in the old folklore tradition}

1. Names used in order to protect the newborn:

A. Male anthroponyms: Обeuar;

B. Female anthroponyms: Oбuua;

2. Names used to wish the newborn good fortune:

A. Male anthroponyms: Алтун, Аргир, Аржентин, Аурел, Бисер, Бриялнт, Гердан, Гривно, Ажемо, Аиаманди, Елмаз, Есмералд, Замфир, Зеро/Зерьо, Злат, Круне/Круньо, Малам, Маламатен, Маламен, Маграрит, Медал, Мено, Плумо, Пубин, Смарагд, Сребрен, Сребро, Сребгр, Хрис, Хрисаф;

B. Female anthroponyms: Алтьна, Аргира, Аргириде, Аржентина, Асима, Аурелия, Бисера, Брияянта, Гердана, Гривна/Гривня, Ажема, Ажофера, Аиаманда, Елмаз, Елмаза, Есмералда, Замфира, Злата, Златиста, Золотинка, Корона, Круна, Малама, Маргарита, Мена, Перла, Пмума, Рубина, Смарагда, Сребра, Сребряна, Сребърна, Хриса, Хрисава, Хрисафи, Хриси.

There are only two protective names - one male and one female. Обецан and Обица were initially given to children born to a family after the parents had had a stillborn baby. An earring was put in one of his/her ears to save the child from death.

Unfortunately, most of the forenames presented in this article are used very rarely nowadays. Today the highly popular tendency that can be observed consists of parents' choice of so-called international names for newborn children to ensure that the latter would not have any problems in the future if they decide to settle down in another country. The fashion is not only valid for Bulgarians but for all Europeans.

This is probably not the only reason for the possible future disappearance of forenames whose meaning refers to precious stones, metals, and jewels as active elements of the Bulgarian anthroponymic system. Most old traditional Bulgarian names are derived from dialect words and their semantics is not familiar to everybody. That is why they are sometimes accepted as ridiculous or archaic.

As authors, we believe that the more information about personal names whose meaning refers to precious stones, metals, and jewelry is collected and properly 
presented to the general public, the bigger the possibility is for those names to be preserved. We must not forget that they represent a significant element of our national identity, folk traditions, history, and past.

\section{References}

Felecan, O. 2009. Romanian-Ukrainian Connections in the Anthroponymy of the Northwestern Part of Romania. In Names in Multi-Lingual, Multi-Cultural and Multi-Ethnic Contact, Proceedings of the 23 ${ }^{\text {rd }}$ International Congress of Onomastic Sciences, August 11-22, 2008, York University, Toronto, Canada. http://yorkspace.library.yorku.ca/xmlui/bitstream/handle/10315/3973/icos23_399.pdf (accessed June 9, 2013).

Ilchev, S. 1959. Речник на мичните и фамилните имена у българите [Dictionary of Bulgarian personal and family names]. София: ИзАателство на БАН.

Kovachev, N. 1987а. Честотно-тблковен речник на мичните имена у българите [Thesaurus of Bulgarian personal names]. София: А-р Петър Берон.

Kovachev, N. 1987b. Българска ономастика [Bulgarian onomastics]. София: Индекс 80.

Kovachev, N. 1995. Честотно-етимологичен речник на мичните имена в съвременната българска антропонимия [Etymological dictionary of the personal names in Bulgarian contemporary anthroponymy]. Велико Търново: Пик.

Theory 1986: Теория и методика ономастических исследований [Theory and methodology of onomastic research]. Москва: Наука.

Zaimov, Yo. 1994. Български именник [Bulgarian anthroponymicon]. София: ИзАателство на БАН.

\section{Index of Bulgarian male forenames denoting precious stones, metals, and jewelry}

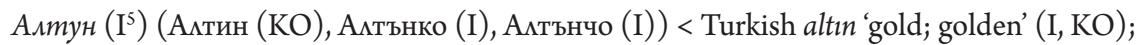

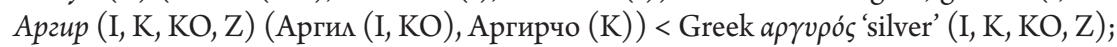
Аржентин (I) < Romanian argint 'silver' (I);

Aурел (I, K, KO) (Аврел (I), Аурелиан (KO), Аурелиен (KO), Аурелио (KO), Аурелиян $(\mathrm{KO})$, Аурика $(\mathrm{K}))<$ Latin aureus, 3 'golden; gold-plated, gilded' (I, K, KO);

Бисер (I, K, KO, Z) (Бисерин (КО), Бисерко (Z), Бисерчо (КО)) < Bulgarian 6uсер 'pearl' (I, K, Z);

Брилянт (I, KO) (Бриян (KO)) < Bulgarian брияянт < French brillant 'brilliant' (I, KO);

Гердан (I, KO) < Bulgarian гердан < Persian-Turkish gerdan 'necklace' (I, KO);

Гривно (Z) < Гривна/Гривня (I, KO, Z);

Ажемо $(\mathrm{K}, \mathrm{KO})<$ Ажема $(\mathrm{K}, \mathrm{KO})$;

Аиаманди (I, K, KO) (Аайманди (I), АиаманА (I, KO), Аиамант (I, KO), Аиаманти (KO),

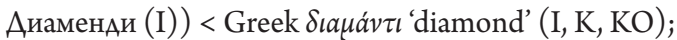

Eıмаз $(\mathrm{K}, \mathrm{KO})<1)$ Bulgarian елмаз < Arabic-Turkish älmäs/elmas 'diamond' (K), 2) Eıмаз $(\mathrm{KO})$;

Eсмералд (K) < Есмералда $(\mathrm{K}, \mathrm{KO})$;

Замфир (I, K, КО) (Завир (I), Занфир (КО), Занфираки (I), Зафир (I, K, Z), Зафирко (I,

5 The following abbreviations are used in both indexes: Ilchev 1959= I, Kovachev 1987a = K, Kovachev $1995=$ KO, Zaimov $1994=$ Z. 
K), Зафирчо (К), Земфир (КО), Зефир (I), Сафар (I), Сафир (I)) < Greek бáцфєıро ‘ 'sapphire' (I, K, KO, Z);

Зеро (I)/Зерьо (I) (Зерко (I)) < Persian-Turkish zer 'gold' (I);

Злат (I, K, KO, Z) (ЗАакьо (I), Знатан (I, K, KO, Z), Златанко (I, K, Z), Зматанчо (K, KO, Z),

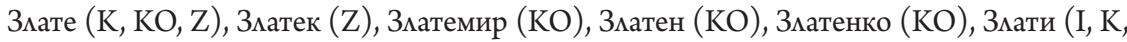

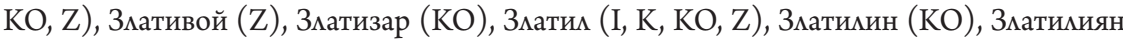

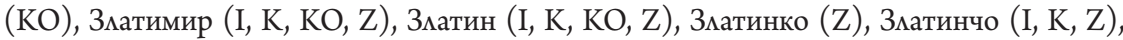

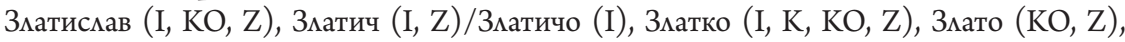

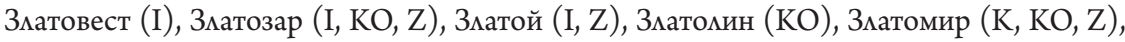
Златосвет (Z), ЗАатослав (I, K, KO, Z), Златоцвет (KO, Z), Зматуй (I, Z), Зматун (Z),

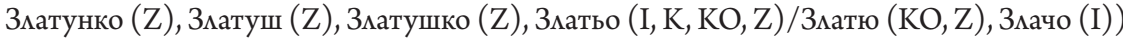
$<$ Bulgarian (dialect) злаm 'golden' (I, K, KO, Z);

Круне (I)/Круньо (I) (Крунислав (I)) < Круна (I);

$\operatorname{Ma\wedge aм}(\mathrm{I})<\operatorname{Ma\wedge aмa}(\mathrm{I}, \mathrm{K})$;

Маламатен (I) > Bulgarian (dialect) маламатен 'golden; gilded' (I);

Маламен (I) (Маламан (I), Маламин (I), Маламчо (I)) < Bulgarian (dialect) маламатен 'golden; gilded' (I);

Mаргарит (I, K, КО) (МаркариА (КО), Маркарит (KO)) < Bulgarian маргарит < Greek

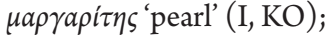

$\operatorname{Meдa\wedge ~(K)~<~Russian~медаль~'medal'~(K);~}$

Мено (I, K, KO, Z) (Мендо (KO), Менко (I, K, KO, Z), Менкул (Z), Менто (I, Z), Ментун (I, Z), Ментуш (I), Менцо (I), Менчо (I, K, KO, Z), Меньо (I, KO, Z)/Меню $($ KO, Z) $<$ Мена (I, KO, Z);

Обецан (I) < Bulgarian (dialect) обецан 'a male with an ear-ring on his ear' (I);

$\Pi_{\text {мумо }}(\mathrm{K})<\Pi_{\text {мума }}(\mathrm{I}, \mathrm{K}, \mathrm{KO})$;

Рубин (I, К, КО) (Рубинко (I)) < Bulgarian рубин 'ruby' (I, K, КО);

Смарагд (I) (Змаряди (I), Смарагди (KO), Смаради (I), Смарайди (I, K, KO), Смарандьо (I), Шмарай (I)) < Смарагда (I, KO);

Сребрен (I, K, KO, Z) (Сребренко (KO), Сребренчо (KO), Сребрил (Z), Сребрила (Z), Сребрин (I, K, KO, Z)) < Bulgarian (dialect) сребрен '(made of, resembling) silver, argentine' (I);

Сребро (I, K, KO, Z) (Сребко (I, KO), Сребран (K, KO), Сребре (Z), Сребри (KO), Сребромир (KO), Среброзар (I, KO), Сребрьо (I, K, KO, Z)/Сребрю (KO, Z), Сребрян (KO), Сребчо (I, KO)) < Bulgarian сребро 'silver' (I, KO);

Сребър (I, KO, Z) (Сребърко (I, Z), Сребърчо (KO)) < Bulgarian (dialect) сребър '(made of, resembling) silver, argentine' (I, KO, Z);

Хрис (I) (Хрисан (I), Хрисен (I), Хрисиан (К, КО), Хрисимир (К), Хрисин (I), Хрисио

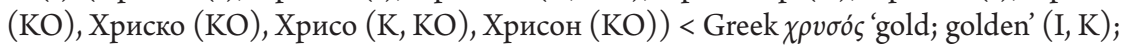

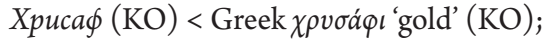

\section{Index of Bulgarian female forenames denoting precious stones, metals, and jewelry}

Алтъна (I, KO) (Алтана (I, KO), А^тина (KO), Алтинка (KO), А^тънка (I, KO), А^тяно (I)) $<$ Turkish altın 'gold; golden' (I, KO); 
Apгupa (I, K, KO, Z) (Аргила (KO), Аргирита (KO), Аргирка (K, КО), Аргирица (K, КО), Аргирия (I), Аргирука (KO)) < Аргир (I, K, KO, Z);

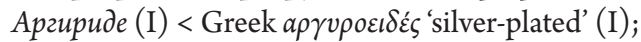

Аржентина (I, K) < 1) Аржентин (I), 2) Latin Argentum, i, n 'silver' (K);

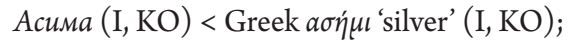

Aурелия (I, K, KO) < Latin aurea (feminine form of the adjective aureus, 3) 'golden' (K);

Бисера (I, K, KO, Z) (Бисерина (КO, Z), Бисериона (KO), Бисерия (KO), Бисерка (I, K,

KO, Z), Бисира $(\mathrm{KO}))<$ Бисер (I, K, КО);

Брилянта (I, KO) (Бримянтина (I)) < Брилянт (I, KO);

Гердана (I, KO) (Герданка (KO)) < Гердан (I, KO);

Гривна $(\mathrm{KO}, \mathrm{Z}) /$ Гривня (I, KO, Z) (Гримна (KO), Гримня $(\mathrm{I}, \mathrm{KO}))<$ Bulgarian гривна) гривня 'bracelet' (I, KO, Z);

Ажема (K, KO) (Ажемма (KO)) < English Jemma < Italian Gemma < Latin gemma 'jewelry, jewel' $(\mathrm{K}, \mathrm{KO})$;

Ажофера (KO) (Ажоферка (KO)) < Bulgarian (dialect) джовер/джувер 'jewel' (KO);

Аиаманда (KO) (Аиамандула (KO), Аиаманка (I), Аиаманта (KO), Аиамантка (KO), Аиамантийка (KO), Аиамантия (KO)) < Аиаманди (I, K, КО);

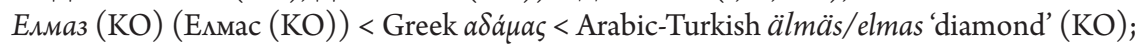

Eлмаза $(\mathrm{K}, \mathrm{KO})($ Елмазка $(\mathrm{KO}))<$ Елмаз $(\mathrm{K})$;

Eсмералда (K, КО) (Исмералда (KO)) < Spanish esmeralda 'emerald' (K, KO);

Замфира (I, K, КО) (Завира (I), Завирка (I), Замферия (КО), Замфирица (I), Замфирка (I, K, КО), Занфира (I, КО), Занфирица (КО), Занфирка (КО), Занхиринка (I), Зафира $(\mathrm{I}, \mathrm{K})$, Зафири (K), Зафирица (I, K), Зафиричка (K), Зафирка (I, K, Z), Зафирула (K), Земфира (КО), Земфирка (КО), Зефира (I)) < Замфир (I, К, КО, Z);

3лата (I, K, KO, Z) (Злака (I), Златана (I, K, KO, Z), Златанка (I, K, KO, Z), Злателина (KO),

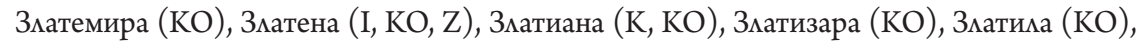

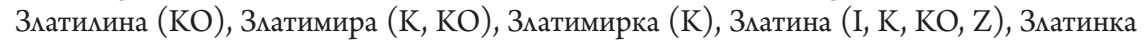
(I, K, KO, Z), Зматискава (I, KO, Z), Зматица (I, K, KO, Z), Зматия (I, KO, Z), Зматка (I, K, KO, Z), Златна (I, KO, Z), Златовеска (KO), Златоема (KO), Златоживка (Z), Златозара $(\mathrm{K}, \mathrm{KO}, \mathrm{Z})$, Златозария (KO), Златозарка (I, K, KO, Z), З九атолилия (KO), Златолина (I,

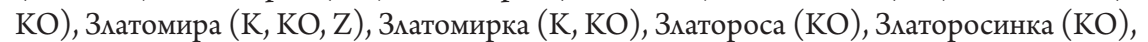

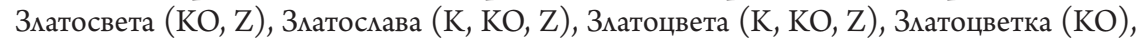
Златуна (KO, Z), Златунка (KO, Z), Златуша (KO, Z), Златушка $(\mathrm{KO}, \mathrm{Z}))<1)$ 3лат (I, $\mathrm{K}, \mathrm{Z}), 2)$ Bulgarian злаmo 'gold' (KO);

3ıатиста (KO) < Bulgarian зıатиста 'golden' (KO);

Золотинка (I) < Russian золото 'gold' (I);

Корона (KO) < Russian корона 'crown' (KO);

Круна (I) < Bulgarian (dialect) круна 'crown' (I);

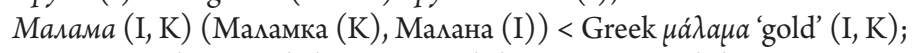

Mаргарита (I, K, KO) (Маргарета (K), Маргаретка (K), Маргаритка (K, KO), Маргерита

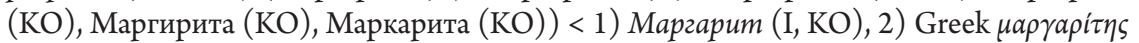
'pearl' (K, Z);

Мена (I, K, KO, Z) (Менда (KO), Мендуха (KO), Меневша (KO), Менека (КО), Менекша (KO), Менешка (KO), Менка (I, K, KO, Z), Менке (I), Менча (I, KO, Z)/Менче (I, KO)) $<$ Bulgarian (dialect) мена 'engagement ring' (I, KO, Z);

Обица (KO) (Обичка (KO)) < Bulgarian обица 'earring' (I, KO); 
Перла (I, K, КО) (Перлет (КО), Перлита (КО)) < 1) French perle 'pearl' (I, KO), 2) Bulgarian nерла 'pearl' (K);

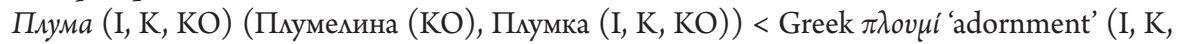
$\mathrm{KO})$;

Рубина (К, КО) (Рубинка (К, КО), Рубиня (КО)) < Рубин (I, К, КО);

Смарагда (I, K, KO) (Змарагда (KO), Змарагдина (КО), Змараица (I), Змарайда (KO), Смарайда (I, K, KO), Смарайдица (I), Смарайдуца (I), Смаранда (I, K), Старайда (I)) < Bulgarian смарагд < Greek $\sigma \mu \alpha \rho a ́ \gamma \delta$ เ 'emerald' (I, KO);

Сребра (I, K, KO, Z) (Сребка (I), Сребрана (K, KO), Сребранка (K), Сребрена (I, K, KO, $\mathrm{Z})$, Сребренка (K, KO, Z), Сребриета (K), Сребрина (I, K, KO, Z), Сребринка (K, KO), Сребрица (KO), Сребрия (I, KO), Сребруна (KO), Сребъра (KO), Сребърка (KO), Сребъртина (KO)) < 1) Сребро (I, KO), 2) Сребър (I, KO, Z);

Сребряна (I, KO, Z) (Сребрянка (KO)) < Bulgarian (dialect) среберена '(made of, resembling) silver, argentine' (I);

Сребърна (I, KO) < Bulgarian сребърна '(made of, resembling) silver, argentine' (I, KO);

Хриса (I, К, КО) (Хрисана (К, КО), Хрисанка (К, КО), Хрисимира (К), Хрисина (КО), Хрисинка (KO), Хрисия (KO), Хриска (I, K, KO), Хрисна (KO), Хрисо (I), Хрисона (I, КО), Хрисонка (I, K, КО), Хрисоня (КО), Хрисопея (КО), Хрисука (I), Хриша (I),

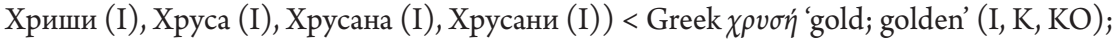

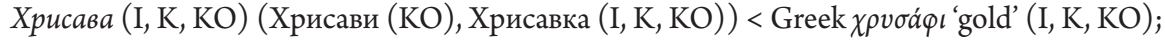
Хрисафи (I, КО) (Хрисафа (I, КО), Хрисафена (КО), Хрисафеня (КО), Хрисафина (КО))

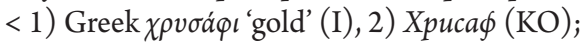

Хриси (I, К, КО) (Хрисена (КО), Хрисиана (КО), Хрисианна (КО), Хрисияена (КО),

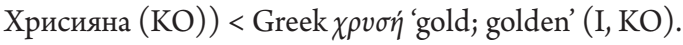

